\title{
Problematyka
}

Kultura i jej wytwory; ontologia artefaktów; metodologia badań literaturoznawczych i kulturoznawczych; teoria; literaturoznawstwo porównawcze; tendencje w kulturze/literaturze; związki interdyscyplinarne; pogranicza kultury/literatury i filozofii, antropologii, socjologii etc.; zmiany paradygmatów; trendy i konteksty; syntezy teoretycznoliterackie i kulturoznawcze - oraz obszary zbliżone.

\section{Polityka wydawnicza}

Z wyjątkiem tekstów zamawianych oraz nowych i pierwszych tłumaczeń tekstów obcojęzycznych $\operatorname{Er}(r)$ go nie drukuje tekstów uprzednio publikowanych. Przedruki są dopuszczalne w numerach tematycznych, jeżeli tekst jest szczególnie istotny merytorycznie dla całościowej koncepcji numeru. Nadesłane teksty podlegają procedurze podwójnie anonimowej recenzji (double-blind peer review), której wynik decyduje o ostatecznym zakwalifikowaniu tekstu do publikacji.

\section{Forma tekstu}

1. Teksty należy nadsyłać przez system OJS w edytowalnym formacie (DOC, DOCX lub RTF - nie: PDF). W tym celu należy wejść na stronę www.errgo.pl, zalogować się do systemu jako "Autor", a następnie postępować zgodnie z instrukcjami.

2. Tekst polskojęzyczny należy formatować zgodnie ze zmodyfikowanym stylem Chicago Humanities:

- $\quad$ interlinia: podwójna

- $\quad$ marginesy: $3 \mathrm{~cm}$ (lewy, prawy, górny i dolny)

- font: Times New Roman, stopień pisma: 12 punktów

- $\quad$ wcięcie akapitu: $1,25 \mathrm{~cm}$; justowanie: obustronne

- $\quad$ tytuł artykułu: maksimum 120 znaków ze spacjami

- $\quad$ streszczenia w języku polskim i angielskim min. 600 i max. 800 znaków ze spacjami.

- $\quad$ słowa klucze: maksimum 75 znaków ze spacjami.

- $\quad$ motto: do 250 znaków ze spacjami, wyłącznie pod głównym tytułem, stopień pisma 10 pkt.

- $\quad$ śródtytuły: maksimum 70 znaków ze spacjami, nagłówki nienumerowane

- cytat blokowy: minimum trzy linie lub 50 słów, interlinia pojedyncza, bez cudzysłowu, wcięcie bloku - 1,25 cm, odstęp od tekstu głównego - jedna linia z góry i z dołu, stopień pisma 10 punktów (nie: kursywa!)

- $\quad$ cytat w cytacie blokowym: cudzysłów podwójny górny (“Tekst”)

- cytat w tekście: maksimum trzy linie - cudzysłów podwójny (“Tekst”)

- cytat w cytacie w tekście: cudzysłów pojedynczy ("Tekst 'tekst' tekst".)

- $\quad$ wyrazy użyte w specjalnym sensie: cudzysłów podwójny (“Tekst”)

- $\quad$ wyróżnienia: wyłącznie kursywą (nie: rozstrzelenie, nie: pogrubienie)

- $\quad$ elipsa: [...]

- $\quad$ przecinki i kropki: za cudzysłowem (“Tekst 'tekst' tekst”.)

- $\quad$ odsyłacze przypisu: przed znakiem przestankowym (“Tekst 'tekst' tekst”.) 
3. Wszelkie ryciny i ilustracje cudzego autorstwa zamieszczone w tekście należy nadesłać także przez system OJS jako "pliki pomocnicze", w rozdzielczości minimum 300 dpi. Do ilustracji należy dołączyć licencję właściciela praw autorskich na wykorzystanie materiału w druku i w wersji online lub, w przypadku materiałów na licencjach otwartych, określenie typu licencji i wskazanie źródła.

4. Przypisy należy przygotować $\mathrm{w}$ formie przypisów dolnych, wedle niżej podanych wskazówek i przykładów (Chicago style):

- $\quad$ Książka: Imię Nazwisko autora, Tytuł, przeł. Imię Nazwisko tłumacza (miejsce wydania: wydawca, rok wydania), strona lub strony.

- Rozdział w książce zbiorowej: Imię Nazwisko autora, “Tytuł rozdziału”, w: Tytuł książki lub tomu zbiorowego, red. Imię Nazwisko redaktora (miejsce wydania: wydawca, rok wydania), strona lub strony.

- $\quad$ Artykuł w periodyku: Imię Nazwisko autora, “Tytuł artykułu”, Tytuł czasopisma tom, numer, rok wydania, strona lub strony.

- $\quad$ Artykuł ze strony internetowej, forum dyskusyjnego lub czasopisma online: Imię Nazwisko autora, “Tytuł artykułu lub postu”, Tytuł czasopisma, tom, numer, rok wydania, http://www.xxx.xxxx.xxx (data dostępu w postaci: dd.mm.rrrr).

- Hasło encyklopedyczne lub słownikowe: "Hasło", w: Tytuł encyklopedii lub słownika, red. Imię Nazwisko redaktora (miejsce wydania: wydawca, rok wydania), strona lub strony. - Hasło z encyklopedii lub słownika internetowego: "Hasło", w: Tytuł encyklopedii lub słownika, http://www.xxx.xxxx.xxx (data dostępu w postaci dd.mm.rrrr).

- Wiersz lub rozdział w ksiażce jednego autora: Imię Nazwisko autora, “Tytuł wiersza lub rozdziału”, w: Tytuł tomu lub książki (miejsce wydania: wydawca, rok wydania), strony. - Film: Tytuł filmu, reż. Imię Nazwisko reżysera, Nazwa dystrybutora lub producenta, kraj, rok premiery.

- $\quad$ Cytat za innym autorem: Imię Nazwisko autora cytowanego tekstu, Tytut, przeł. Imię Nazwisko tłumacza (miejsce wydania: wydawca, rok wydania), strony, cyt. za: Imię Nazwisko autora cytowanego tekstu, Tytuł, przeł. Imię Nazwisko tłumacza (miejsce wydania: wydawca, rok wydania), strona lub strony.

- Kolejne przypisy: Nazwisko autora, skrócony “Tytuł artykułu...” lub Książki..., strona.

\section{Przykłady}

- Książka: Roland Barthes, Sade, Fourier, Loyola, przeł. Renata Lis (Warszawa: Wydawnictwo KR, 1996), 30-31.

- Rozdział w książce zbiorowej: Robert Cieślak, “Od Grünewalda do Bacona. Gra o tożsamość w poezji Tadeusza Różewicza”, w: Ponowoczesność a tożsamość, red. Bożena Tokarz, Stanisław Piskor (Katowice: Wydawnictwo OK SPP, 1997), 86-87.

- $\quad$ Artykuł w periodyku: Ewa Szczęsna, “Tożsamość hybrydyczna”, Er(r)go nr 9, 2/2004, 10-11.

- Artykuł ze strony internetowej, forum dyskusyjnego lub czasopisma online: Artur Wolski, "Nauka i przemyślenia”, Forum Akademickie, 1/2006, http://forumakademickie.pl/fa/2006/01/nauka-i-przemyslenia (12.02.2007). 
- Hasło encyklopedyczne lub słownikowe: “Rozum”, w: Słownik synonimów, red. Andrzej Dąbrówka, Ewa Geller, Ryszard Turczyn (Warszawa: Wydawnictwo MCR, 1993), 115-116. - Hasło z encyklopedii lub słownika internetowego: “Absolut”, w: Powszechna Encyklopedia Filozofii, http://www.ptta.pl/pef/pdf/a/absolut.pdf (10.10.2007).

- Wiersz lub rozdział w książce jednego autora: Maria Korusiewicz, "Vermeer (1658)”, w: Majolika (Katowice: Wydawnictwo Śląsk, 2012), 5.

- Film: The Pillow Book, reż. i scen. Peter Greenaway, Lions Gate Films, Francja-Holandia-Wielka Brytania, 1996.

- Cytat za innym autorem: Kurt Vonnegut, Jr., Rzeźnia numer pięć, przeł. Lech Jęczmyk (Warszawa: Wydawnictwo Da Capo, 1996), 14, cyt. za: Jolanta Misiarz, “Jeszcze kilka słów na temat masakry. Filozofia egzystencjalna w Rzeźni numer pięć”, w: Szkice o literaturze i kulturze amerykańskiej, red. Teresa Pyzik (Katowice: Wydawnictwo Uniwersytetu Śląskiego, 2001), 71.

- $\quad$ Kolejne przypisy: Vonnegut, Rzeźnia..., 132-133.

6. Nie stostujemy skrótów: “ibid./ibidem”; “op. cit.”; “tamże”; “tegoż”.

7. Skrót: “Zob.” stosujemy wtedy, kiedy naszą intencją jest poszerzenie podawanych informacji. Skrót "Por." stosujemy wtedy, kiedy naszą intencją jest komparatywne lub kontrastywne zestawienie podawanych informacji z innym źródłem.

8. Do każdego tekstu prosimy dołączyć jednoakapitowe streszczenia w języku angielskim i polskim (wraz z tytułem w języku angielskim i słowami kluczowymi w obu językach) - min. 600 i max. 800 znaków ze spacjami, a także bibliografię załącznikową (instruktaż: https://support.microsoft.com/pl-pl/office/apa-mlachicago-\%e2\%80\%94-automatyczne-formatowanie-bibliografii-405c207c-707042fa-91e7-eaf064b14dbb?ui=pl-pl\&rs=pl-pl\&ad=pl).

\section{Standardy językowe}

Nadesłane teksty artykułów i streszczeń muszą spełniać międzynarodowe standardy akademickiej angielszczyzny (poziom językowy wykształconego native-speakera języka angielskiego) oraz akademickiej polszczyzny.

\section{Zastrzeżenia}

Redakcja zastrzega sobie prawo do dokonywania pewnych modyfikacji tekstu nienaruszających merytorycznej strony opracowania. Teksty niekompletne oraz teksty opisane niekompletnymi metadanymi będą odrzucane. Redakcja zastrzega sobie prawo do przedruków tekstu w numerach rocznicowych Er(r)go.

\section{Korespondencja}

Korespondencję prosimy kierować na adres e-mail: errgo@us.edu.pl. 



\section{Themes}

Culture and its products; the ontology of artefacts; methodologies of literary and cultural research; critical theory; comparative literary studies; trends and tendencies in culture/literature; interdisciplinary relations; liminal spaces between culture, literature, philosophy, anthropology, sociology, etc.; transformations of paradigms; trends and contexts; literary-theoretical and cultural syntheses - and related areas.

\section{Editorial policy}

Except for commissioned texts, or new (first) translations, $\operatorname{Er}(r)$ go does not accept texts previously published. Reprints are admissible in thematic issues if a given text is particularly important from the point of view of the overall conception of the issue. Submissions undergo the procedure of double-blind peer review, the outcome of which decides about the qualification of the text for publication.

\section{Text formatting}

1. Editable documents (DOC, DOCX or RTF - not: PDF) should be submitted to our OJS system. In order to do this, please visit the journal's website (www.errgo. $\mathrm{pl}), \log$ in to the system as "Author" and follow the on-screen instructions.

2. Texts in English should be prepared in accordance with the Chicago style:

- $\quad$ spacing: double space

- $\quad$ margins: $3 \mathrm{~cm}$ (left, right, top and bottom)

- font: Times New Roman, font size: 12 points

- paragraph indent: $1.25 \mathrm{~cm}$; justification: left and right

- $\quad$ article title: maximum 120 characters including spaces

- abstracts in English and in Polish: min. 600 and max. 800 characters including spaces

- $\quad$ keywords: $\max 75$ characters including spaces

- $\quad$ motto: max. 250 characters incl. spaces, exclusively under the main title, font size: 10 points

- $\quad$ subsection headers: maximum 70 characters including spaces; headers unnumbered

- blockquote: minimum three lines or 50 words, single-spaced, no quotation marks

- block indent: $1.25 \mathrm{~cm}$, one empty line between the main text and the text of the quote (top and bottom), font size: 10 points. Do not italicize blockquotes.

- quotations withing the blockquote: double quotation marks (“Text")

- $\quad$ in-text quotations: maximum three lines - double quotation marks

- $\quad$ quotations within in-text quotations: single quotation marks (“Text 'text' text.")

- $\quad$ special use of words: double quotation marks (“Text”)

- $\quad$ emphasis: only italics (not: spaced, not: bold)

- $\quad$ ellipsis: [...]

- commas and periods: within quotation marks (“Text 'text' text.")

- $\quad$ footnote number: after the period and/or quotation mark (“Text 'text' text."1) 
3. All of the graphic material (figures, illustrations, diagrams, etc.) to be included in the text should be submitted via OJS as "additional files." The minimum resolution of illustrations is $300 \mathrm{dpi}$. All graphics must be supplied with appropriate written licenses for print and online use, issued by the copyright owner or, in the case of open-license or owned materials, a declaration concering the type of the license and the source of the graphics.

4. Footnotes need to be prepared in accordance with the Chicago Humanities style, as follows:

- A book: Name Surname of the author, Title, trans. Name Surname of the translator (place of publication: publisher, year of publication), pages.

- A chapter in a collective volume: Name Surname of the author, "Title of the Chapter," in: Title of the Collection, ed. by Name Surname of the editor(s) (place of publication: publisher, year of publication), pages.

- An article in a periodical: Name Surname of the author, "Title of the Article," Title of the Periodical, volume, issue, year, pages.

- An online article, an online forum entry, an online periodical article: Name Surname of the author, "Title of the Article," Title of the Periodical, volume, issue, year, page (if available), http://www.xxx.xxxx.xxx (access date in the dd/mm/yyyy format).

- An encyclopaedia/dictionary entry: "Title of the Entry," in: Title of the Source, edited by Name Surname of the editor (place of publication: publisher, year of publication), pages. - An online encyclopaedia/dictionary entry: "Title of the Entry," in: Title of the Source, http://www.xxx.xxxx.xxx (access date in the dd/mm/yyyy format).

- A poem or a chapter in a book by a single author: Name Surname of the author, "Title of the Chapter," in: Name Surname of the author, Title of the Book (place of publication: publisher, year of publication), pages.

- Film: The Title of the Motion Picture, dir. Name Surname of the director, Name of the producer or distributor, country, year of release.

- Quotation after a different author: Name Surname of the author of the quoted text, Title of the Book, trans. Name Surname of the translator (place of publication: publisher, year of publication), pages, quoted in: Name Surname of the quoting author, Title of the Book, trans. Name Surname of the translator (place of publication: publisher, year of publication), pages.

- Following footnotes to the same text: Surname of the author, shortened "Title of the Article" or of a Book, pages.

\section{Examples}

- A book: Jean Baudrillard, The Ecstasy of Communication, trans. Bernard and Caroline Schutze, edited by Sylvere Lotringer (New York: Semiotext(e), 1988), 30-31.

- A chapter in a collective volume: Robert Cieślak, "Od Grünewalda do Bacona. Gra o tożsamość w poezji Tadeusza Różewicza," in: Ponowoczesność a tożsamość, edited by Bożena Tokarz and Stanisław Piskor (Katowice: Wydawnictwo OK SPP, 1997), 86. 
- An article in a periodical: Ewa Szczęsna, “Tożsamość hybrydyczna,” Er(r)go, No. 9, 2/2004, 10-11.

- An online article, an online forum entry, an online periodical article: Artur Wolski, "Nauka i przemyślenia," Forum Akademickie 1/2006, http://forumakademickie.pl/fa/2006/01/ nauka-i-przemyslenia (12.02.2007).

- An encyclopaedia/dictionary entry: “Rozum," in: Słownik synonimów, edited by Andrzej Dąbrówka, Ewa Geller, Ryszard Turczyn (Warszawa: Wydawnictwo MCR, 1993), 115-116. - An online encyclopaedia/dictionary entry: "Absolut," in: Powszechna Encyklopedia Filozofii, http://www.ptta.pl/pef/pdf/a/absolut.pdf (10.10.2007).

- A poem or a chapter in a book by a single author: Maria Korusiewicz, "Vermeer (1658)," in: Majolika (Katowice: Wydawnictwo Śląsk, 2012), 5.

- Film: The Pillow Book, dir. and screenplay Peter Greenaway, Lions Gate Films, France-the Netherlands-United Kingdom, 1996.

- $\quad$ Quotation after a different author: Kurt Vonnegut, Jr., Rzeźnia numer pięć, trans. Lech Jęczmyk (Warszawa: Wydawnictwo Da Capo, 1996), 14, quoted in: Jolanta Misiarz, "Jeszcze kilka słów na temat masakry. Filozofia egzystencjalna w Rzeźni numer pięć," in: Szkice o literaturze i kulturze amerykańskiej, edited by Teresa Pyzik (Katowice: Wydawnictwo Uniwersytetu Śląskiego, 2001), 71.

- $\quad$ Footnotes to the same text: Vonnegut, Rzeźnia numer pięć, 132.

6. We do not use: "ibid./ibidem"; “op. cit."; "idem”.

7. We use "See:" only when it is our intention to extend the information provided in the text. The abbreviation "Cf." is to be used only when our intention is to provide a contrastive or comparative juxtaposition of the information offered in our text with information offered in other sources.

8. Each text must be appended with one-paragraph abstracts in English and Polish (including titles and keywords in both languages), min. 600 and max. 800 characters (including spaces), and with attachment bibliography formatted according to Chicago standards (refer to: https://support.microsoft.com/en-us/office/apa-mla-chicago-\%e2\%80\%93-automatically-format-bibliographies-405c207c7070-42fa-91e7-eaf064b14dbb?ui=en-us\&rs=en-us\&ad=us).

\section{Langruage standards}

Submissions, including abstracts, must meet the world-wide standards of academic English (educated native speaker proficiency level).

\section{Disclaimer}

The Editors reserve the right to introduce modifications that would not affect the merit of the study to the texts submitted to $\operatorname{Er}(r) g o$. Incomplete submissions, or submissions missing metadata will be rejected. The Editors also reserve the right to reprint texts submitted to the journal in anniversary or special issues of the $\operatorname{Er}(r) g o$.

\section{Correspondence}

Correspondence should be directed to: errgo@us.edu.pl. 